IJ§ER

ISSN: 2149-5939
International Journal of Social Sciences and Education Research

Online, https://dergipark.org.tr/tr/pub/ijsser

Volume: 7(1), 2021

\title{
A critical discourse analysis of a news report on two mosques shooting in Christ- church-New Zealand
}

\author{
Aminuddin Hashemi ${ }^{\mathrm{a}^{*}}$ and Kew Si Na \\ *Corresponding author \\ ${ }^{a}$ Takhar University, Taloqn, Takhar Province, Afghanistan. E-mail: aminuddin.hashemi@gmail.com ORCID: https://orcid.org/0000-0002- \\ $\underline{8132-7878}$ \\ ${ }^{b}$ School of Education, Faculty of Social Science and Humanity, University Teknologi Malaysia Email: snkew@utm.my ORCID: http://or- \\ cid.org/0000-0001-6648-6806
}

\begin{tabular}{ll}
\hline Article Info & Abstract \\
\hline Research Article & News reports are regarded as a reflection of world reality. People around the world are \\
& watching the news reports to get the first aid information about incidents or events they \\
Received:9 November 2020 & need. Hence, languages in the news reports are, of course, considered neutral, impartial, \\
Revised: 9 December 2020 & and unbiased. Thus, this paper attempts to provide a critical discourse analysis CDA of a \\
Accepted: 16 December 2020 & news report in its online version taken from the Guardian newspaper regarding the mass \\
& shooting of the Muslims in Christchurch, New Zealand. In this respect, Halliday's systematic \\
Keywords: & functional grammar is employed to explore the linguistic features along with two CDA's \\
Mass shooting in Christ- & tools (nominalization and passivization). Moreover, the researcher used these different tools \\
church, & of discourse analysis to unfold the use of biased language in this news report. For achieving \\
Guardian newspaper, & with its tools initially. Afterward, there is an interpretation and discussion of the analysis \\
CDA 's tools, & which is adopted based on CDA tools. However, the result of the analysis unfolded that \\
Halliday's SFG, & Guardian news reports concerning the two Mosques shooting in Christchurch, New Zealand \\
Linguistic features & were not remained unbiased in reporting such sensitive issues. The implication for the jour- \\
& nalists is to keep always their impartiality in advance while reporting any incidents or \\
& events.
\end{tabular}

\section{Introduction}

It is a fact that in this contemporary world of technology people turned to various resources of information like; social media, newspapers, and televisions to keep updated on the important incidents happening around the world. In some countries, media is regarded as their pillar to reinforce democracy and freedom of speech. The number of languages and discourses is being transmitted to people via different types of media which the role of a newspaper is considered prominent in manipulation. Fowler (1991) indicates that newspapers are not impartial in reporting the different events specifically when they follow a viewpoint. Therefore, when an event happens around the world the news reports are different in terms of their ideologies and the terminologies they use to a piece of specific news. However, news reports have recently been the center of much critical discourse analyst's attentions to unfold the language biased of the journalists in their reports.

The present paper aims to achieve its goal by using different analytical tools of critical discourse analysis CDA to find out the linguistic features and the ideology of the news report about the Christchurch mosques shooting. To achieve the objectives, this study is going to answer the following questions:

1. What linguistic features are used in the news report of the Guardian about Christchurch mosques shooting in New Zealand?

2. What ideology is covered behind the Guardian's newspaper report?

In what follows, the researcher will introduce the paper initially with the theoretical background on which the paper is based. Afterward, the paper will mainly focus on and analyze the article which is available on Guardian's 
website in its online version. To do so, the report will be analyzed for Transitivity and, the researcher will go through mainly two discourse analytical tools of CDA (nominalization and passivization) to analyze the article. Finally, the analysis process will be carried out and the findings along with the conclusion will be discussed respectively.

\section{Literature review}

News reports are increasingly analyzed by many discourse analysts in the last few decades. Mahfouz (2013) analyzed two Egyptian news reports Al-Gomhuria and Al-Dostour which was mainly focusing on Police news. He explored the ideological aspects of the two newspapers using the framework of critical discourse analysis. The result of the study on these mentioned newspapers revealed that the language is manipulated in terms of the beliefs of the newspaper's audience (Mahfouz, 2013, p. 309). While another research was done by Ghannam (2012) on six Lebanese newspapers, he aimed to identify the ideology laid behind the text that limits the freedom of thoughts and choices of the newspaper's author. The system of transitivity, activation, and passivization is used in the article. The study revealed that different newspaper carries over different ideological aims through language manipulation. Ghannam (2012) believed that a language is a tool that is intentionally manipulated to interlace the covered interpretation of the newspaper's expectation.

Donkin (2012) explored online newspapers and applied three-dimensional models of Fairclough. She used Existential, propositional and valuable tools to analyze the articles in terms of ideological constructs. The study revealed that "online newspaper portrayals of the Chaplaincy Program are predominantly biased based upon the assumptions made by journalists, and the people they choose to represent in their news articles" (p. iii). Similarly, he investigated two Australian newspapers to determine the ideological constructs of racism using adopting a critical discourse analysis CDA framework. The study concluded the ideology covered behind these two Australian newspapers (The Daily Telegraph and The Sydney Morning) as the white majority dominate the other ethnic groups of the Australian community. The result also has been revealed that two Australian news agencies "reflect and reinforce the marginalization of the current Vietnamese immigrants into Australia" (Teo, 2012).

Finally, based on the literature reviewed above, we concluded that each literature comprises different ideologies and different purposes are embedded in their reports based on different political ideologies. The literature shows there is bias in the language of the news reports accordingly. According to critical discourse analysis views, different news reports opposed different ideologies to demonstrate and report various events based on social and political perspectives. To consider media in general and the online newspapers in specific are embedded with covered ideologies and discourse structures are manipulated.

\section{Theoretical background}

\subsection{What is "discourse"?}

The concept of discourse has been defined differently by the researchers based on the contexts in which they applied. The discourse researchers previously considered the concept of discourse from a linguistic viewpoint. Van Dijk (1997) viewed “discourse as a form of spoken language”. Later, Van Dijk (1998) considered discourse as part of language where the language is used in social contexts. Discourse requires social interaction, expressing feelings, ideas, and beliefs through which language is used for communication (Van Dijk 1997). On the other hand, Van Dijk (1997) is also dealing with discourse as a social dimension that illustrates the relationship between society and language.

\subsection{What is critical discourse analysis?}

Critical discourse analysis CDA is considered both an approach and discourse analytical research tool to uncover hidden ideologies and to reveal the issue of power. Critical discourse analysis CDA mainly focuses on how language is related to society Ndambuki \& Janks (2010: 73). As mentioned above, the main objective of critical discourse analysis is to examine how power, ideology, and discourse are constructed by language as a tool. Thus, Van Dijk as an efficient pioneer of critical discourse analysis CDA pointed out as analytical research that studies "the way social power abuse, dominance, and inequality are enacted, reproduced and resisted by text and talk in the social and political context (2001: 352). In this regard, the most well-known discourse analysts like Fairclough, Van Dijk, Wodak, and Fowler primarily initiated this link.

CDA is also considered a multi-dimensional system that can allow different approaches to be used based on its purposes. As the current paper investigates a news report, Fairclough's linguistic approach will be used as one 
of the well-characterized approaches to CDA. This approach allows us to use different analytical tools in the analysis of the news report. There are three dimensions of analysis characterized by Fairclough as follow:

- Discourse as text

- Discourse as a discursive practice

- Discourse as social practice

The first dimension which truly focuses on linguistic features of the text will be our concern in the present paper. Concerning this, Halliday's systematic functional grammar SFG was investigated by Fairclough in a discourse analysis Bloomaert (2005:29).

\subsection{Systematic functional grammar $S F G$}

Systematic functional grammar SFG has initially emerged from British and European language studies. Later, Michael Halliday developed this approach and its focus is on the social context that is related to the structure and forms. SFG is considered a basis for Fairclough's approach to critical discourse analysis CDA. Therefore, SFG is vital for CDA as it concerns and interprets language as meaningful behavior. Mayr (2008) argued that language is socially constructed and embedded in the culture that can be useful for its application in CDA.

The systematic functional grammar suggests three meta-functions in language namely, the ideational function, the interpersonal, and the textual function. Ideational function refers to the experience and understanding of the world. The interpersonal function is concerned with how we interact with other people, raise our thoughts, beliefs, influence behavior, and judgments. Finally, the focus of the textual function is about the structure and the organization of the language system which is called cohesion and coherence. In the present paper, we attempt to use the ideational function of the meta-functional process mainly the transitivity system which involves processes, participants, and circumstances. There are mainly six processes involved in the system of transitivity: material, mental, behavioral, verbal, relational, and existential.

\section{Methods}

Critical discourse analysis is employed to explore the use of discourse concerning social and cultural problems and questions whether the discourse is used in a specific way and what the ramifications of this form of use are. The relation between the use of language and the social and political contexts in which it happens is discussed by critical discourse research. It addresses topics such as gender, race, cultural differences, and ideology and explains how all these are constructed and expressed in texts. The study of critical discourse considers the use of vocabulary that is often social and represents and builds the social world (Rogers, 2004:5). Thus, the current paper draws on Fowler, Halliday, and Fairclough's methods, and the elements set out below are used as a basis for research.

Therefore, the present critical discourse analysis paper has attempted to analyze a news article critically which is available in its online version in Guardian's newspaper based on Halliday's systematic functional grammar and CDA's tools. This sample news is published on March 15, 2019, about shooting Muslims in two mosques in Christchurch New Zealand. Hence, Halliday's systematic functional grammar is employed to explore the linguistic features and ideology covered in the sample news report. Thus, the focus is on the ideational function mainly with the system of transitivity. Besides, two (CDA) tools, nominalization, and passivization are also employed to identify the hidden ideology covered in this news report.

\section{Data analysis}

This section involves the analysis of the discursive practices utilized in the news report of the Guardian's newspaper. The article is revolved around the recent shooting of Muslim mosques in New Zealand.

\subsection{Transitivity}

As a tool for ideological analysis, the following table is shown based on the system of transitivity to give a clear idea of each process type which is used in the Guardian's news report.

Table 1. Shows the total processes of the study

\begin{tabular}{cccccc}
\hline Material process & Relational process & Verbal process & Mental process & Behavioral process & Existential process \\
\hline 80 & 73 & 31 & 17 & 9 & 6 \\
\hline
\end{tabular}


If we consider Table 1, we can easily identify that the material process is dominated and has a leading position in this news report. According to Halliday, the material process is the process of acting and 'doing' something. It shows how some entity does something or may be affected by some other entities. The following examples have been taken out from the news article to show how the entity has done the action and who has been affected by whom.

Table 2. Material process

\begin{tabular}{clcl}
\hline Section number & Actor & Material process & Affected \\
\hline 1 & $\ldots \ldots \ldots \ldots \ldots \ldots \ldots \ldots \ldots \ldots$ & shot & Muslims \\
\hline 1 & $\ldots \ldots \ldots \ldots \ldots \ldots$ & Injured & Muslims \\
\hline 3 & Police & Arrested & $\ldots \ldots$ \\
\hline 4 & Brenton Tarrant & Shooting & Muslims \\
\hline 10 & $\ldots \ldots \ldots \ldots \ldots$ & Killed & Muslims \\
\hline
\end{tabular}

From Table 2 one can understand that all the affected people were Muslims in two mosques and the "actor" was named as 'killer', 'shooter' and 'man'. What is interesting in this sample news report, the actor is mentioned with different names as pointed out in the preceding line. What is more, the reporter has mentioned the words 'killed' and 'shot' two times respectively in a different section. But there are no other words like 'Muslim' mentioned except in the first section. The witness also described the actor who killed dozens of people as a gunman and shooter rather than any other sensitive words. To add more, the dead are described in the nominal form like victims.

Based on the first sentence as described in the initial section of the news report, the writer attempted to show the salience of the people who were killed and injured rather than mentioning who killed them. For instance: "Forty-nine people have been shot dead and 48 injured in attacks targeting Muslims at two mosques". To consider this, the reporter depicted the victims as the affected people.

Table 3. Mental processes

\begin{tabular}{cccc}
\hline Section number & Experiencer (sensor) & Mental process & Experiencer (phenomenon) \\
\hline 3 & Police & Determined & How they might be involved \\
\hline 18 & $\begin{array}{c}\text { They (Killer, shooter, } \\
\text { gunman) }\end{array}$ & See & Religion \\
\hline 22 & Len Peneha, a witness & Heard & $\begin{array}{c}\text { Dozens of shots, followed by people run- } \\
\text { ning away in terror. }\end{array}$ \\
\hline
\end{tabular}

As it is shown on Table 3, there are three mental processes used to reflect different perceptions. Concerning the first one, police as the sensor or experiencer are not sure whether the killers are directly involved in killing the Muslims or not. However, in the second mental process a witness as sensor depicted directly the gunman as an extremist who killed the Muslims. He also accused the shooter as the one who sees religion rather than people. On the other hand, Len Peneha another witnesses conservatively mentioned that a dozen shoots have been heard as experiencers and phenomena. Since the Muslims are always indicated as the experience of the phenomenon, the audience can illustrate the killer as an extremist and terrorist. Dealing with another type of process, some examples of verbal processes are represented in the following Table 4.

Table 4. Verbal process

\begin{tabular}{clll}
\hline Section number & Sayer & Verbal process & Verbiage \\
\hline 2 & Jacinda Ardern & Described & the atrocity as a terrorist attack \\
\hline 2 & $\begin{array}{l}\text { Police commissioner } \\
\text { Mike Bush }\end{array}$ & Said & explosive devices in a car had been defused \\
\hline 2 & $\begin{array}{l}\text { Police commissioner } \\
\text { Mike Bush }\end{array}$ & Urged & $\begin{array}{l}\text { All mosques across the country to close their doors for } \\
\text { the time being. }\end{array}$ \\
\hline 8 & $\begin{array}{l}\text { Scott Morrison (The } \\
\text { Australian prime min- } \\
\text { tster) }\end{array}$ & called & the massacre a "right-wing extremist attack" \\
\hline 8 & Jacinda Ardern & Condemned & the ideology of the people behind the shootings, \\
\hline 17 & Mohammed, a Fijian & Said & his son-in-law was shot in the shoulder \\
\hline
\end{tabular}

The use of the verbal processes shows that different Sayers are involved in this news report and presented their ideas from various angles. Therefore, I will try to take a look at two people who were directly involved and are responsible. To do so, Jacinda Ardern the prime minister of New Zealand as the sayer described the atrocity as a 
terrorist attack. While Scott Morrison the Australian Prime Minister as sayer called the massacre a "right-wing extremist attack". Furthermore, Arden as Sayer condemned the ideology of the people behind the shooting as she felt the sensitivity of the case. Finally, these verbiages allow the readers to illustrate the terms killer, shooter, extremist, terrorist, and fundamentalist.

\section{Nominalization}

Nominalization is the process of changing a verb into a noun or its nominal form to keep the tense situation to be secret. Journalists or newsmakers always use the technique of exploiting a nominal form of the word to manipulate the role of participants. On many occasions, the writer used nominal words to prevent giving much information. Here are some examples used in this news report which have been italicized.

1. "Forty-nine people have been shot dead and 48 injured in attacks targeting Muslims at two mosques during Friday prayers in Christchurch, in the worst mass shooting in New Zealand's history."

2. "The Prime Minister, Jacinda Ardern, described the atrocity as a terrorist attack and said Friday had been "one of New Zealand's darkest days".

3. "New Zealand's entire police arsenal and personnel were deployed throughout the country and end masse in Christchurch, the South Island's largest city, which is known to have an active white-supremacist subculture."

4. " "As dusk fell, people who escaped the two shootings returned to the scene, where they waited."

According to the above examples, the writer attempted to use nominal words on many occasions. Most of the nominal words are used to avoid giving much information on various occasions. At the same time, the writer expected to use these words to diminish the saliency of the action. On the other hand, the newsmaker tried to be unbiased, independent, and keep his talent to be not explored. Furthermore, the aim of using these words can be shown not fomenting to the sensitivity of the issue among Muslims and non-Muslims. In sum, these transformational techniques are used to reduce the gravity of the action in this news report.

\section{Passivization}

Mostly, the newsmakers use the passivization technique to hide the doer of the action in the following two situations: a) to make it more salient and b) consciously, keeping the doer of the action secret. Concerning the first sentence of the writer, two purposes can be detected as follow: "Forty-nine people have been shot dead and 48 injured in attacks targeting Muslims at two mosques during Friday prayers in Christchurch, in the worst mass shooting in New Zealand's history." The first reason for using such a sentence is to keep the agent (doer) secret as the audience can understand and infer who has killed these people but rather the writer used passive voice to make the number of the dead and the injured people more salient.

The same process goes to another sentence that the writer passivizes the word not to hide the doer of the action but to make the action itself more eminent. As can be seen in the following sentence: A "manifesto" was posted online before the attacks."

\section{Interpretation and explanation}

Several techniques have been used in this sample news report and the writer does ideological work on various occasions. At the first stage, the use of material processes is dominant in this news report and allows the reader to identify Muslims as victims affected by an extremely terrorist attack. Similarly, the use of mental processes circulates on a different ideology of naming the killer as a terrorist or extremist. More specifically, these processes carry the same ideology that the writer remained biased while using uncertain words for the terrorist, as the agent and the affected Muslims as dead. Furthermore, the use of verbal processes portage different ideologies as the writer viewed different opinions from different people. This can allow the reader to observe whether what to name the killer or are these terms used in this news report are wielding as the right word? Or there is always something hidden behind these reports.

This sample news report will be regarded as an inequitable report in the history of news reporting around the world in terms of such mass shootings of innocent people based on our analysis. The reporter used different choices of words to convey his ideological views from a particular position. For instance, he used the terms, killers, shooters, and gunmen for the terrorists and the use of all these choices may be considered to influence the readers toward terrorism attacks by non-Muslims. Similarly, the writer of this sample news report has also illustrated 
inconspicuously the terrorists who killed tens of Muslims and injured tens of others. Therefore, the reflection of ideology can be simply identified in this news report and it can be also considered as the example of ideological biased conveyed by the writer.

As the last stage of the analysis, the current sample news reports is explained in terms of the journalisms criteria. According to the journalisms rules and criteria a correspondent is expected to keep his or her impartiality while reporting an incident whether it is war, peace, social and or even any related issues to the society. From the above analysis, we figured out that news reporting is no easy task or the news reports are not self-sufficient for the newsmakers. Thus, the result of this study shows that the writer of this report opposed his political ideologies through language manipulation. Besides, language is used as a tool to be manipulated consciously to meet the hidden ideologies and expectations of the writer. More generally, it is so difficult to find out any news report which is not associated with governmental institutions and political parties.

\section{Conclusion}

The current paper employed the critical discourse analysis using a news article from Guardian's newspaper in its online version concerning the two mosques attack in Christchurch, New Zealand. The present paper has tried to unfold the ideological bias of the author's perspective regarding the perception of terrorism, extremism, and racism concerning the mass shooting of the Muslims in New Zealand. It is identified that the language in the news report of Guardian's newspaper is by no means neutral concerning the mass shooting of the Christchurch Mosques. The result of the current analysis also indicates that the Guardian's news reporter reported this incident for the interests of their own religious beliefs and thoughts. Most importantly, the study of this news article tells us that critical analysis is of great importance in helping news readers not only to gain a deeper understanding of what they are reading but also to learn more about the social and cultural context. To increase critical sensitivity and understanding, critical analysis can benefit newsreaders. Besides, the result of different processes in analyzing the report revealed that the writer of this report could not keep his impartiality and does some ideological biases. Moreover, the first implication of the present paper shows that critical discourse analysis is an effective way to allow the readers of the news report for a better understanding of what they read and for the journalists to keep always their impartiality in advance while reporting any incidents or events. However, the second implication helps the students in particular and the readers of newspapers in general, to be aware of the language manipulation. Finally, the findings of this study suggest newsmakers and journalists remain unbiased in reporting such sensitive incidents.

\section{Author contribution statements}

A. Hashemi and K.S. Na contributed equally to the design and implementation of the research, to the analysis of the results and to the writing of the manuscript.

\section{Disclosure statement}

No potential conflict of interest was reported by the authors.

\section{Ethics committee approval}

All responsibility belongs to the researchers. All parties were involved in the research of their own free will.

\section{References}

Blommaert, J. (2005). Discourse: A Critical Introduction. Cambridge: Cambridge University Press.

Donkin, A. (2012). Australian national school chaplaincy program: A critical discourse analysis of online newspaper portrayals. Unpublished BA thesis, Edith Cowan University, Perth, Australia.

Fowler, R. (1991). Language in the News: Discourse and ideology in the press. London: Routledge.

Ghannam, N. (2012). Newspaper ideology: A critical discourse analysis of an event published in six Lebanese newspapers. Unpublished Master's thesis, University of the Witwatersrand, South Africa. Retrieved from http://wiredspace.wits.ac.za/bitstream/handle/10539/11267/NADA\%20FINAL\%20checked\%2 0by\%20JInggs.pdf?sequence=1

Mahfouz, A. R. (2013). A critical discourse analysis of the police news story framing in two Egyptian newspapers before the January 25 revolution. European Scientific Journal, 9(8), 309-332.

Mayr, A. (2008). Introduction: Power, discourse, and institutions. In A. Mayr, Language and Power: An Introduction to Institutional Discourse (pp. 1-25). London: Continuum International.

Copyright (C) by IJSSER, 2021

ISSN: 2149-5939 
Ndambuki, J., \& Janks, H. (2010). Political Discourses, Women's Voices: Mismatches in Representation. Critical Approaches to Discourse Analysis across Disciplines.

Rogers, R., 2004. An Introduction to Critical Discourse Analysis in Education. Mahwah, NJ: Laurence Erlbaum Associates Inc.

Slembrouck, S. (2010). Discourse Analysis. In K. Malmkjær, the Routledge Linguistics Encyclopedia (3rd ed., pp. 133-137). New York: Routledge.

Teo, P. (2000). Racism in the news: a critical discourse analysis of news reporting in two Australian newspapers.Discourse Society, 11(7), 7-49. http://dx.doi.org/10.1177/0957926500011001002

Van Dijk, T. A. (1997). The study of discourse. In T. A. Van Dijk (Ed.), Discourse as structure and process (Vol.1, pp. 1-35). London: Sage.

Van Dijk, T. A. (1998). Ideology: A multidisciplinary study. London. Sage Publications.

Wodak, R. (2001). What CDA is about: A summary of its history, important concepts, and its developments? In R.

Wodak \& M. Meyer (Eds.), Methods of critical discourse analysis (pp. 1-13). London: Sage

Aminuddin Hashemi is a junior lecturer in the English department of language and literature faculty at Takhar University, Afghanistan. His research interests are teaching and learning, Teaching English as a Second Language (TESL), Technology Enhanced Language Learning (TELL), Computer Assisted Language Learning (CALL), Critical Discourse Analysis (CDA), etc

Kew Si Na is a senior lecturer in the language academy, faculty of social science, school of education at Universiti Teknologi Malaysia. Her research interests are English Language Teaching and learning, Online Teaching and Learning, Learning Analytics (LA), Digital literacy, technology-based education, etc. 


\section{APPENDIX}

49 shot dead in attack on two Christchurch mosques

Mar 15, 2019, Eleanor Ainge Roy in Christchurch and Lisa Martin

The Guardian

1. Forty-nine people have been shot dead and 48 injured in attacks targeting Muslims at two mosques during Friday prayers in Christchurch, in the worst mass shooting in New Zealand's history.

2. The Prime Minister, Jacinda Ardern, described the atrocity as a terrorist attack and said Friday had been "one of New Zealand's darkest days". Police commissioner Mike Bush said explosive devices in a car had been defused and urged all mosques across the country to close their doors for the time being.

3. A man in his late 20s was arrested and charged with murder. He will appear in court on Saturday morning. Two other armed suspects were being held in custody. Police said they were trying to determine how they might be involved.

4. Police have not named any of the suspects, but a man identifying himself as Brenton Tarrant, a 28-year-old born in Australia, broadcast live stream footage on Facebook showing him driving to a mosque, entering and shooting randomly at people inside.

5. New Zealand's entire police arsenal and personnel were deployed throughout the country and en masse in Christchurch, the South Island's largest city, which is known to have an active white-supremacist subculture.

6. Hotels in the inner city stationed security guards at their entrances and armed police protected landmarks of significance, including the courthouse and Christchurch hospital, which is believed to have been a further target. A Christchurch spokesperson told local media police were concerned the suspects had plans to target the victims of the mosque attack as they were transported to the hospital.

7. A "manifesto" was posted online before the attacks, in which the suspected gunman espoused far-right and antiimmigrant ideology.

8. The Australian Prime Minister, Scott Morrison, called the massacre a "rightwing extremist attack" and said one suspect was Australian-born, without giving further details. Ardern condemned the ideology of the people behind the shootings, saying: "You may have chosen us but we utterly reject and condemn you."

9. New Zealand's threat level has been raised from low to high. None of the suspects were on terrorism watchlists, Ardern said.

10. As dusk fell, people who escaped the two shootings returned to the scene, where they waited at the police cordon in an attempt to reach an unknown number of people still being held in a back room of Al Noor mosque, where 30 people were killed in the first attack. Ten people were later killed at the Linwood Islamic Centre, four miles $(6 \mathrm{~km})$ away.

11. Relatives of those inside estimated about 100 people remained locked inside the mosque.

12. A trickle of Christchurch residents stood with the victims keeping vigil, rubbing their shoulders, offering food and logistical support. "We're so sorry," they repeated, and: "This is not us, this is not New Zealand." Some in typical New Zealand fashion were using black humour, evidently as a coping mechanism in the midst of an overwhelming tragedy.

13. Hassan, 29, a Sri Lankan Muslim who has lived in New Zealand for six months, said he came to the country for its "peace, and because there are no wars". He did not wish to give his last name.

14. He was at the Linwood mosque's Friday prayer service when the shooting began, and hit the floor as women around him rose up and screamed at the gunmen "Do not come here," some of them charging towards the gunman.

15. "The shooter was screaming a lot and waving the gun in every direction, shooting, shooting, shooting," he said. "I don't know who of my friends is dead or alive now. I am waiting. Police told me: 'I am sorry; this is the first time this has ever happened in this country.", 
16. Hassan's home is within the Al Noor police cordon, and he was unable to return on Friday night.

17. Mohammed, a Fijian Muslim who also did not wish to give his last name, was in Al Noor mosque when the shooting started. He escaped through the back door, but said his son-in-law was shot in the shoulder and his nephew was trapped inside

18. "I am happy that I am alive," he said. "I am new to New Zealand and at the mosque you find your friends and family. They are after the Muslims. They only see religion ... They don't see people any more.

19. "We are not safe anymore. Where are we safe now?"

20. As shots rang out, police put the city in lockdown and evacuated nearby climate change protests, with children separated from their relatives looked after by council staff until it was safe.

21. Those who live near the two mosques reported people climbing over fences to escape, and begging for help as the massacre unfolded.

22. The gunman entered Al Noor mosque in central Christchurch and opened fire at $1.40 \mathrm{pm}$ local time. An estimated 400 people were inside for Friday prayers. Len Peneha, a witness, told Associated Press he saw a man dressed in black go into the mosque and heard dozens of shots, followed by people running away in terror.

23. He said he saw the gunman flee before the emergency services arrived. Peneha said he went into the mosque to try to help: "I saw dead people everywhere."

24. Another man who was at the mosque told TVNZ he had not seen his wife, who was also in the mosque, since the shooting. The man, who was in a wheelchair, pushed himself out to the car park.

25. "It was very peaceful, calm and quiet, as it is when the sermon starts, you could hear a pin drop. Then suddenly the shooting started," he said. "I saw about 20-plus people, some were dead, some were screaming. On the left there were 10-plus people, some were dead."

26. The killer or killers then moved on to the Linwood mosque and killed a further 10 people. In a statement just after $4 \mathrm{pm}$ local time, the police said Christchurch was in lockdown and urged people to stay indoors.

27. A Christchurch hospital spokesman said some victims were being treated at the emergency department but he could not provide numbers because the hospital was in lockdown.

28. The mayor of Christchurch, Lianne Dalziel, said the city was in shock: "This has come as a bolt from the blue ... It just feels like it's not what would happen in a place like New Zealand."

29. Earlier, Ardern said many of those directly affected by the shooting might be migrants to New Zealand.

30. "They have chosen to make New Zealand their home, and it is their home. They are us," she told reporters. "The person who has perpetuated this violence against us is not. They have no place in New Zealand."

31. Members of the Bangladesh cricket team, who were outside Al Noor mosque when the shootings occurred, were unhurt. The team were due to play the final Test match of their New Zealand tour in Christchurch on Saturday. The game was cancelled. The New Zealand cricket team sent its "heartfelt condolences" in a post on Twitter.

32. All team members and staff caught up in the incident returned safely to their hotel, Bangladesh Cricket confirmed, after taking refuge in the immediate aftermath of the attack in the dressing rooms at Hagley Oval.

33. The Australian Department of Foreign Affairs and Trade has urged Australians in Christchurch to follow the instructions of local authorities, but has not changed its travel advice from normal safety precautions.

34. As the swell of family members grew outside the cordon at Al Noor mosque, local Christchurch residents began walking to the scene on foot, carrying flowers and laying them beneath a tree, and approaching survivors offering help.

35. Elsewhere, Christchurch seemed eerily deserted, the pubs and restaurants that would usually be bustling on a Friday closed as the city mourned. 